\title{
Challenges for the Autoimmunologist
}

\author{
Torsten Matthias • Yehuda Shoenfeld
}

Published online: 25 June 2009

(C) Humana Press Inc. 2009

\begin{abstract}
Every 2 years, an International Congress of Autoimmunity is organized and held with the intent of creating a new base for continuing interdisciplinary and international research, including further opportunities to train in the field of autoimmunity. In September 2008, the Congress of Autoimmunity was held in Porto, Portugal, and over the next 6 months, requests were made from a number of key investigators to provide copies of their papers for publication in a special volume of this journal. In addition, a satellite meeting sponsored by the AESKU.KIPP Institute was held in Porto with an attempt of focusing on specific challenges faced by the autoimmunologist. It is hoped that this collection of papers will become a valuable source for researchers in autoimmunity.
\end{abstract}

The AESKU.KIPP Institute, much like the focus of the Congress of Autoimmunity, attempts to create a new base for continuing interdisciplinary and international research and further training in the field of autoimmunity. The institute is distinguished by the extraordinary synthesis of networked scientific competence and clear orientation to practical issues; it provides ideal conditions for the timely implementation of current research into new diagnostic and therapeutic options. The AESKU.KIPP INSTITUTE initiates and coordinates international research cooperation and development projects. At the same time, it offers the spatial and personnel requirements for the implementation of joint interdisciplinary projects at the Wendelsheim facility. To create a unique platform for

\footnotetext{
T. Matthias

AESKU.KIPP INSTITUTE, Mikroforum Ring,

355234 Wendelsheim, Germany

Y. Shoenfeld $(\square)$

Department of Medicine B and Research Center

of Autoimmune Disease, Sheba Medical Center,

Tel Hashomer 52621, Israel

e-mail: shoenfel@post.tau.ac.il
}

interdisciplinary research in autoimmunity, the AESKU.KIPP INSTUTUTE is supported by an active advisory council of experts in autoimmunity committed to the aims of the institute. Under the roof of the nonprofit association of Association for Interdisciplinary Research in Autoimmunity e.V., the AESKU. KIPP INSTITUTE intentionally creates openness towards a diversity of cooperation partners in science and economy, thus providing an ideal environment for the interdisciplinary orientation of its activities and the generation of true benefit for the public. Via an active information policy including symposia and publications, it presents current possibilities of prognosis, diagnostics, and therapy to the public, for the benefit of patients and treating physicians.

This issue contains papers which address problems in rheumatoid arthritis, lupus, the use of the biologics, the antiphospholipid antibody syndrome, postpericardial injury syndromes, the use of intravenous immunoglobulin, the future of stem cell transplantation, the biology of amyloid disease, recent data on both celiac disease as well as infection in autoimmunity, and finally a number of unique problems that are often discussed but require further attention. These include studies of antifibrotic agents, mastocytosis, environment and health, and new diagnostic techniques in autoimmunity. Obviously, it is a potpourri of subjects and is not intended to be a complete overview of cutting-edge issues. We note that there have been dedicated issues of the other official journals of the meeting, Autoimmunity Reviews and the Journal of Autoimmunity, which likewise focus on critical issues for the autoimmunologist. Finally, towards this end, we were asked to provide a list of some of these papers as well as related publications in these journals that focus on some interesting and key problems in autoimmunology that will be helpful and which address such subjects as immunoregulation, organspecific autoimmune disease, new diagnostic techniques, the biologics, innate immunity, and cellular and molecular mechanisms that focus on loss of tolerance. The following is a brief list of some relevant citations [1-40] and include, in 
particular, subjects that will be addressed in the next Congress of Autoimmunity in Slovenia in May 2010.

\section{References}

1. Abraham NG, Li M, Vanella L, Peterson SJ, Ikehara S, Asprinio D (2008) Bone marrow stem cell transplant into intra-bone cavity prevents type 2 diabetes: role of heme oxygenase-adiponectin. J Autoimmun 30:128-135

2. Akeno N, Blackard JT, Tomer Y (2008) HCV E2 protein binds directly to thyroid cells and induces IL-8 production: a new mechanism for HCV induced thyroid autoimmunity. J Autoimmun 31:339-344

3. Askenasy N, Kaminitz A, Yarkoni S (2008) Mechanisms of T regulatory cell function. Autoimmun Rev 7:370-375

4. Baker RL, Wagner DH Jr, Haskins K (2008) CD40 on NOD CD4 $\mathrm{T}$ cells contributes to their activation and pathogenicity. J Autoimmun 31:385-392

5. Bartunkova J, Kayserova J, Shoenfeld Y (2009) Allergy and autoimmunity: parallels and dissimilarity: the yin and yang of immunopathology. Autoimmun Rev 8:302-308

6. Bazzani C, Filippini M, Caporali R, Bobbio-Pallavicini F, Favalli EG, Marchesoni A, Atzeni F, Sarzi-Puttini P, Gorla R (2009) AntiTNF alpha therapy in a cohort of rheumatoid arthritis patients: clinical outcomes. Autoimmun Rev 8:260-265

7. Boren EJ, Cheema GS, Naguwa SM, Ansari AA, Gershwin ME (2008) The emergence of progressive multifocal leukoencephalopathy (PML) in rheumatic diseases. J Autoimmun 30:90-98

8. Burt RK, Testori A, Craig R, Cohen B, Suffit R, Barr W (2008) Hematopoietic stem cell transplantation for autoimmune diseases: what have we learned? J Autoimmun 30:116-120

9. Caturegli P, Lupi I, Landek-Salgado M, Kimura H, Rose NR (2008) Pituitary autoimmunity: 30 years later. Autoimmun Rev 7:631-637

10. Dalloul A (2009) CD5: a safeguard against autoimmunity and a shield for cancer cells. Autoimmun Rev 8:349-353

11. Fenalti G, Rowley MJ (2008) GAD65 as a prototypic autoantigen. J Autoimmun 31:228-232

12. Greene MT, Ercolini AM, DeGutes M, Miller SD (2008) Differential induction of experimental autoimmune encephalomyelitis by myelin basic protein molecular mimics in mice humanized for HLA-DR2 and an MBP(85-99)-specific T cell receptor. J Autoimmun 31:399-407

13. Hogan TV, Ang DK, Gleeson PA, van Driel IR (2008) Extrathymic mechanisms of $\mathrm{T}$ cell tolerance: lessons from autoimmune gastritis. J Autoimmun 31:268-273

14. Hu N, Westra J, Kallenberg CG (2009) Membrane-bound proteinase 3 and its receptors: relevance for the pathogenesis of Wegener's granulomatosis. Autoimmun Rev 8:510-514

15. Ingegnoli F, Fantini F, Favalli EG, Soldi A, Griffini S, Galbiati V, Meroni PL, Cugno M (2008) Inflammatory and prothrombotic biomarkers in patients with rheumatoid arthritis: effects of tumor necrosis factor-alpha blockade. J Autoimmun 31:175-179

16. Jennings $P$, Chan A, Schwartzberg P, Wakeland EK, Yuan D (2008) Antigen-specific responses and ANA production in B6. Sle1b mice: a role for SAP. J Autoimmun 31:345-353

17. Jordan MA, Baxter AG (2008) The genetics of immunoregulatory T cells. J Autoimmun 31:237-244

18. Katzav A, Ben-Ziv T, Chapman J, Blank M, Reichlin M, Shoenfeld Y (2008) Anti-P ribosomal antibodies induce defect in smell capability in a model of CNS-SLE (depression). J Autoimmun 31:393-398

19. Kerr EC, Raveney BJ, Copland DA, Dick AD, Nicholson LB (2008) Analysis of retinal cellular infiltrate in experimental autoimmune uveoretinitis reveals multiple regulatory cell populations. J Autoimmun 31:354-361
20. Klein RS, Sayre RM, Dowdy JC, Werth VP (2009) The risk of ultraviolet radiation exposure from indoor lamps in lupus erythematosus. Autoimmun Rev 8:320-324

21. La Cava A (2008) Tregs are regulated by cytokines: implications for autoimmunity. Autoimmun Rev 8:83-87

22. Lleo A, Battezzati PM, Selmi C, Gershwin ME, Podda M (2008) Is autoimmunity a matter of sex? Autoimmun Rev 7:626-630

23. Lleo A, Selmi C, Invernizzi P, Podda M, Gershwin ME (2008) The consequences of apoptosis in autoimmunity. J Autoimmun 31:257-262

24. Marmont AM (2008) Will hematopoietic stem cell transplantation cure human autoimmune diseases? J Autoimmun 30:145-150

25. Marttila J, Huttunen S, Vaarala O, Suzuki K, Elliott JF, Narvanen A, Knip M, Simell O, Ilonen J (2008) T-cell reactivity to insulin peptide A1-12 in children with recently diagnosed type 1 diabetes or multiple beta-cell autoantibodies. J Autoimmun 31:142-148

26. Mathieu A, Paladini F, Vacca A, Cauli A, Fiorillo MT, Sorrentino R (2009) The interplay between the geographic distribution of HLA-B27 alleles and their role in infectious and autoimmune diseases: a unifying hypothesis. Autoimmun Rev 8:420-425

27. Miller A, Basu N, Luqmani R (2008) Assessment of systemic vasculitis. Autoimmun Rev 8:170-175

28. Neuhausen SL, Steele L, Ryan S, Mousavi M, Pinto M, Osann KE, Flodman P, Zone JJ (2008) Co-occurrence of celiac disease and other autoimmune diseases in celiacs and their first-degree relatives. J Autoimmun 31:160-165

29. Pai S, Thomas R (2008) Immune deficiency or hyperactivity-NFkappa b illuminates autoimmunity. J Autoimmun 31:245-251

30. Perricone R, Perricone C, De Carolis C, Shoenfeld Y (2008) NK cells in autoimmunity: a two-edg'd weapon of the immune system. Autoimmun Rev 7:384-390

31. Rezvani AR, Storb RF (2008) Separation of graft-vs.-tumor effects from graft-vs.-host disease in allogeneic hematopoietic cell transplantation. J Autoimmun 30:172-179

32. Schulze C, Munoz LE, Franz S, Sarter K, Chaurio RA, Gaipl US, Herrmann M (2008) Clearance deficiency-a potential link between infections and autoimmunity. Autoimmun Rev 8:5-8

33. Shimoda S, Miyakawa H, Nakamura M, Ishibashi H, Kikuchi K, Kita H, Niiro H, Arinobu Y, Ono N, Mackay IR, Gershwin ME, Akashi K (2008) CD4 T-cell autoreactivity to the mitochondrial autoantigen PDC-E2 in AMA-negative primary biliary cirrhosis. J Autoimmun 31:110-115

34. Shoenfeld Y, Selmi C, Zimlichman E, Gershwin ME (2008) The autoimmunologist: geoepidemiology, a new center of gravity, and prime time for autoimmunity. J Autoimmun 31:325-330

35. Sitia S, Atzeni F, Sarzi-Puttini P, Di Bello V, Tomasoni L, Delfino L, Antonini-Canterin F, Di Salvo G, De Gennaro Colonna V, La Carrubba S, Carerj S, Turiel M (2009) Cardiovascular involvement in systemic autoimmune diseases. Autoimmun Rev 8:281-286

36. Skorstad G, Hestvik AL, Vartdal F, Holmoy T (2009) Cerebrospinal fluid $\mathrm{T}$ cell responses against glutamic acid decarboxylase 65 in patients with stiff person syndrome. J Autoimmun 32:24-32

37. Szekanecz E, Szucs G, Szekanecz Z, Tarr T, Antal-Szalmas P, Szamosi S, Szanto J, Kiss E (2008) Tumor-associated antigens in systemic sclerosis and systemic lupus erythematosus: associations with organ manifestations, immunolaboratory markers and disease activity indices. J Autoimmun 31:372-376

38. Toplak N, Kveder T, Trampus-Bakija A, Subelj V, Cucnik S, Avcin T (2008) Autoimmune response following annual influenza vaccination in 92 apparently healthy adults. Autoimmun Rev 8:134-138

39. Vital EM, Emery P (2008) The development of targeted therapies in rheumatoid arthritis. J Autoimmun 31:219-227

40. Yeh S, Wroblewski K, Buggage R, Li Z, Kurup SK, Sen HN, Dahr S, Sran P, Reed GF, Robinson R, Ragheb JA, Waldmann TA, Nussenblatt RB (2008) High-dose humanized anti-IL-2 receptor alpha antibody (daclizumab) for the treatment of active, noninfectious uveitis. J Autoimmun 31:91-97 